\title{
The involvement of tet $A$ and tet $E$ tetracycline resistance genes in plasmid and chromosomal resistance of Aeromonas in Brazilian strains
}

\author{
Ilana Teruszkin Balassiano, Maria do Carmo de Freire Bastos, \\ Danielle Jannuzzi Madureira, Iris Gripp da Silva, Ângela Corrêa de Freitas-Almeida*, \\ Selma Soares de Oliveira/ ${ }^{+}$
}

Laboratório de Genética de Bactérias Associadas a Alimentos, Depto de Microbiologia Geral, Instituto de Microbiologia Prof. Paulo de Góes, Centro de Ciências da Saúde, Bloco I, Av. Carlos Chagas Filho 373, Cidade Universitária, Ilha do Fundão, 21.941902 Rio de Janeiro, Brasil *Faculdade de Ciências Médicas, Universidade do Estado do Rio de Janeiro, Rio de Janeiro, Brasil.

This study analyzed the involvement of tet $\mathrm{A}$ and tetE genes in the tetracycline resistance of 16 strains of genus Aeromonas, isolated from clinical and food sources. Polymerase chain reactions revealed that 37.5\% of the samples were positive for tetA, and also $37.5 \%$ were tetE positive. One isolate was positive for both genes. Only the isolate A. caviae 5.2 had its resistance associated to the presence of a plasmid, pSS2. The molecular characterization of pSS2 involved the construction of its restriction map and the determination of its size. The digestion of pSS2 with HindIII originated two fragments (A and B) that were cloned separately into the pUC18 vector. The tetA gene was shown to be located on the HindIII-A fragment by PCR. After transforming a tetracycline-sensitive strain with pSS2, the transformants expressed the resistance phenotype and harbored a plasmid whose size was identical to that of pSS2. The results confirmed the association between pSS2 and the tetracycline resistance phenotype, and suggest a feasible dissemination of tet $\mathrm{A}$ and tetE among strains of Aeromonas. This study suggests the spreading tetA and tetE genes in Aeromonas in Brazil and describes a resistance plasmid that probably contributes to the dissemination of the resistance.

Key words: Aeromonas - plasmid - tetracycline - resistance determinants

The genus Aeromonas includes a group of bacteria present in several natural habitats, such as soil, fresh and brackish water, and sewage (Garibay et al. 2006). They also belong to the amphibiotic microbiota of fishes, reptiles and amphibians (Araujo et al. 1991, Son et al. 1997). This genus has already been isolated from many kinds of foods, like seafood, bovine and swine meat and derivatives, vegetable, salads, ice-cream, milk and cheese (Araújo et al. 2002, Martins et al. 2002, EvangelistaBarreto et al. 2006, Palú et al. 2006 ).

It has been suggested that the high prevalence of Aeromonas species in the environment should be considered a threat to public health, since infections caused by these pathogens are generally the result of ingestion of contaminated water or food (Chopra \& Houston 1999, Alavandi \& Ananthan 2003, Garibay et al. 2006). For that reason, some Aeromonas species have been classified as emerging pathogens (Szabo et al. 2000, Edberg et al. 2007).

In humans, the pathogenic species usually involved in cases of gastroenteritis are A. hydrophila, A. caviae and A. veronii (Edberg et al. 2007). Generally, the infections are self-limiting, and the antibiotic therapy is used only when the infections become severe.

Financial support: CNPq, FAPERJ, PRONEX, FUJB

${ }^{+}$Corresponding author: selma@micro.ufrj.br

Received 11 June 2007

Accepted 24 October
Although the practice of feeding antibiotics to animals as growth enhancers is still an usual practice in some countries like United States, it has been phased out in the European Union and has been desestimulated (Gilchrist et al. 2007). Indeed, for several decades, tetracycline has been widely used in clinical medicine, veterinary and agriculture (Gilchrist et al. 2007), contributing to higher levels of microbial resistance, especially among the genus Aeromonas (Goñi-Urriza et al. 2000).

The resistance to tetracyclines occurs through the presence of tet genes in the bacterial DNA. The characterized tet genes encode three mechanisms of resistance: efflux pump, ribosomal protection or enzymatic inactivation (Chopra \& Roberts 2001).

Many authors have described the presence of tetracycline resistance plasmids in Aeromonas species (Rhodes et al. 2000; Schmidt et al. 2001a; L'Abée-Lund $\&$ Sorum 2002). Genes of the tet family are often associated with conjugative and mobilizable elements, such as plasmids, transposons and integrons (Chopra \& Roberts 2001, Schmidt et al. 2001b). This characteristic could explain their broad distribution among different bacterial species. The molecular characterization of the tet genes and plasmids that carry these resistance determinants may help to explain how human and the environment have been affected by the increase and indiscriminate use of tetracycline. The tetracycline resistance determinants most commonly observed in Aeromonas species are tet $\mathrm{A}$ and tet $\mathrm{E}$ (Schmidt et al. 2001b, Nawaz et al. 2006). For that reason, those genes were chosen for the amplification reactions performed in this work. Both tet $\mathrm{A}$ and tet $\mathrm{E}$ genes code for an efflux pump that removes the drug from the cell (Chopra \& Roberts 2001). 
Therefore, the aim of this study was to characterize, at a molecular level, a tetracycline resistance plasmid found in a strain of $A$. caviae (Ac) isolated from lettuce and to analyze the dissemination of the tetA and tet $\mathrm{E}$ genes among strains of some Aeromonas species isolated in Brazil.

\section{MATERIALS AND METHODS}

Bacterial strains and plasmids - 16 isolates of tetracycline-resistance Aeromonas strains, with minimal inhibitory concentration (MIC) values of $16 \mathrm{mg} \mathrm{ml}^{-1}$ (Palú et al. 2006), listed in Table, were analyzed for the resistance determinants and the presence of plasmids. All strains were grown in LB-agar (Difco, Brazil) according to Schleif and Wesink (1981) containing the selective antibiotic (tetracycline or ampicilin), when necessary. For longterm storage, the bacterial strains were kept at $-70^{\circ} \mathrm{C}$ in LB medium containing 14\% (v/v) glycerol.

Detection of tetracycline resistance determinants The tetracycline-resistance Aeromonas spp. strains were examined for the presence of resistance determinants by polymerase chain reaction (PCR), using specific primers for tetA (Guardabassi et al. 2000) and tet $\mathrm{E}$ (Tovar et al. 1988) genes. Crude lysates were obtained by centrifugating $1 \mathrm{ml}$ of the bacterial growth at $10,000 \mathrm{~g}$ for $4 \mathrm{~min}$. The pellet was resuspended in $1 \mathrm{ml}$ of TE (10 $\mathrm{mM}$ Tris- $\mathrm{HCl}, 1 \mathrm{mM}$ EDTA, $\mathrm{pH}$ 7.8), centrifuged and washed twice, in the same conditions described above. The pellet was resuspended in $100 \mathrm{ml}$ of TE. The suspension was heated for $10 \mathrm{~min}$ at $100^{\circ} \mathrm{C}$ and, after a

TABLE

Tetracycline-resistant Aeromonas strains used in this study

\begin{tabular}{|c|c|c|c|c|}
\hline Strain & $\begin{array}{l}\text { Source/ year of } \\
\text { isolation }\end{array}$ & $\begin{array}{l}\text { Presence } \\
\text { of tet } \mathrm{A}\end{array}$ & $\begin{array}{c}\text { Presence } \\
\text { of tet } \mathrm{E}\end{array}$ & Plasmid \\
\hline Ac 5.2 & Lettuce $^{a} / 2002$ & + & - & pSS2 \\
\hline Ac 6.2 & Lettuce $^{a} / 2002$ & + & - & - \\
\hline Ah 6.4 & Lettuce $^{a} / 2002$ & - & + & - \\
\hline Ah 7.2 & Lettuce $^{a} / 2002$ & - & + & - \\
\hline Ah 16 & Lettuce $^{a} / 2002$ & - & - & - \\
\hline Ac 43 & Cheese $^{a} / 1999$ & + & - & - \\
\hline Ac 36 & Cheese $^{a} / 1999$ & - & + & - \\
\hline Ac 37 & Cheese $^{a /} 1999$ & - & + & - \\
\hline Ac 38 & Cheese $^{a} / 1999$ & - & + & - \\
\hline Ac $\mathrm{C} 8$ & Faeces $^{b} / 1994$ & + & - & - \\
\hline Ac C50 & Faeces $b / 1994$ & - & + & - \\
\hline Ac 314 & Faeces $^{b} / 1994$ & - & - & - \\
\hline Ah 8 & Faeces ${ }^{b} / 1994$ & - & - & - \\
\hline Ah 149 & Faeces $b / 1994$ & + & + & - \\
\hline Ac 95 & $\begin{array}{l}\text { secretion of } \\
\text { respiratory } \\
\operatorname{tract}^{b} / 2002\end{array}$ & + & - & - \\
\hline Ac 26 & $\begin{array}{l}\text { secretion of } \\
\text { respiratory } \\
\text { tract }^{b} / 2002\end{array}$ & + & - & - \\
\hline
\end{tabular}

$a$ : food samples were isolated from lettuce (Palú et al. 2006) and cheese (Araujo et al. 2002); $b$ : clinical samples were obtained from patients of Hospital Universitário Pedro Ernesto, Universidade do Estado do Rio de Janeiro, Rio de Janeiro, Brazil. Ac: A. caviae; Ah: A. hydrophila centrifugation at $10,000 \mathrm{~g}$ for $1 \mathrm{~min}$, the supernatant was recovered and used as template for PCR. The purified plasmid and the recombinant plasmids obtained in the cloning experiments were also used as DNA templates for PCR. The PCR assay was carried out according to the method described by Guardabassi et al. (2000). Acinetobacter sp. RUH $2158 \mathrm{H} 5$, MIC value $\geq 16 \mathrm{mg}$ $\mathrm{ml}^{-1}$ (Guardabassi et al. 2000), and Escherichia coli strain D22-14, MIC value $\geq 10 \mathrm{mg} \mathrm{ml}^{-1}$ (Marshall et al. 1986), were used as positive control in reactions using tet $\mathrm{A}$ and tet $\mathrm{E}$ primers. The Aeromonas strains $A$. caviae 32 and $A$. hydrophila (Ah) 21 (from our collection), both tetracycline-sensitive, were used as negative controls in both PCR reactions. The reaction mix without DNA was also submitted to the amplification reactions. All PCR products were analyzed by electrophoresis in $1.5 \%(\mathrm{w} /$ v) agarose gels in TAE (40 mM Tris-acetate, $1 \mathrm{mM}$ EDTA, pH 7.9) buffer. The 100-bp DNA ladder (Invitrogen, Brazil) was used as a size marker.

Plasmid DNA isolation - All tetracycline-resistant Aeromonas spp., the E. coli host strain of pUC18 and transformants were screened for their plasmid content using the procedure described by Birnboim and Doly (1979), and whole cell lysate method (Sambrook et al.1989). DNA samples were stored at $-20^{\circ} \mathrm{C}$ until the moment of use. The plasmid DNAs were separated by electrophoresis on $0.8 \%(\mathrm{w} / \mathrm{v})$ agarose gels (Sambrook et al. 1989) in TAE buffer.

Transformation - Plasmid pSS2 was used to transform the tetracycline-sensitive strain A. hydrophila (Ah) ATCC 5677. The plasmid pSS2 was purified with the Wizard Plus ${ }^{\mathrm{TM}}$ SV Miniprep kit (Promega, Brazil), and used to transform A. hydrophila ATCC 5677 competent cells by heat-shock (Sambrook et al. 1989). Transformants were selected by growth on LB agar with $10 \mathrm{mg} \mathrm{ml}^{-1}$ of tetracycline, after overnight incubation at $37^{\circ} \mathrm{C}$. Transformant colonies were screened for their plasmid content, as described above.

Restriction endonuclease analysis - Plasmid pSS2 was extracted from strain A. caviae 5.2 (Ac 5.2) using Wizard Plus ${ }^{\mathrm{TM}}$ SV Miniprep kit, and digested with restriction enzymes (Invitrogen) in the conditions recommended by the manufacturer. The enzymes used were $B g l \mathrm{II}, C l a \mathrm{I}, E c o$ RI, EcoRV, HindIII, and XhoI. The restriction fragments obtained in simple and double digestions were separated by electrophoresis in $0.8 \%(\mathrm{w} / \mathrm{v})$ agarose gels in TAE buffer, or in $5 \%(\mathrm{w} / \mathrm{v})$ poliacrylamide gels in TBE (Tris $89 \mathrm{mM}$, boric acid $89 \mathrm{mM}$, EDTA 2.5 $\mathrm{mM}, \mathrm{pH}$ 8.2) buffer. The 1-kb DNA ladder (Invitrogen) was used as a size marker in agarose gels, while the 100-bp DNA ladder (Invitrogen) was used in polyacrylamide gels.

Cloning of the HindIII fragments of pSS2 - Both pSS2 and pUC18 (Yanisch-Pérron et al. 1985) were isolated using Wizard ${ }^{\mathrm{TM}}$ Plus Minipreps DNA Purification System (Promega), and digested with $10 \mathrm{U} / \mathrm{ml}$ of HindIII (Invitrogen), following the recommendations of the manufacturer. Both A and B fragments, generated by the HindIII digestion of pSS2, were individually cloned into 
pUC18 by standard techniques (Sambrook et al. 1989). The recombinant plasmids were used to transform E. coli DH5-a competent cells by heat-shock (Sambrook et al. 1989). Transformants were selected on LB agar with 75 $\mathrm{mg} / \mathrm{ml}^{-1}$ ampicilin, $40 \mathrm{mg} / \mathrm{ml}^{-1}$ IPTG and $75 \mathrm{mg} / \mathrm{ml}^{-1} \mathrm{X}$ $\mathrm{Gal}$, at $37^{\circ} \mathrm{C}$, after overnight incubation. Transformants were screened for their plasmid content as described above.

\section{RESULTS}

Detection of tetracycline-resistance determinants - Amplification only of tetA gene was observed in 37.5\% (6/16) of the analyzed Aeromonas samples (Table, Fig. 1). Three of these strains were isolated from food, while three of them were isolated from clinical sources.

Concerning the amplification of tetE gene, it was also observed that $37.5 \%(6 / 16)$ of the samples were only positive for this resistance determinant (Table, Fig. 2). Five of them were isolated from food, while only one was isolated from a clinical source. It was also noticed that the strain Ah 149, isolated from a clinical source, was positive for the amplification of both tet $\mathrm{A}$ and tet $\mathrm{E}$ genes (Figs 1, 2).The strains Ac314, Ah8 (both isolated from faeces), and Ah16 (isolated from lettuce) were negative for the amplification of both genes. The resistance gene determinant of these strains was not determined in this work.

A

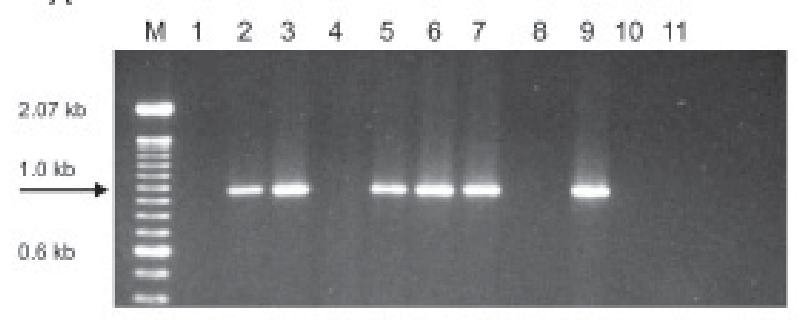

B

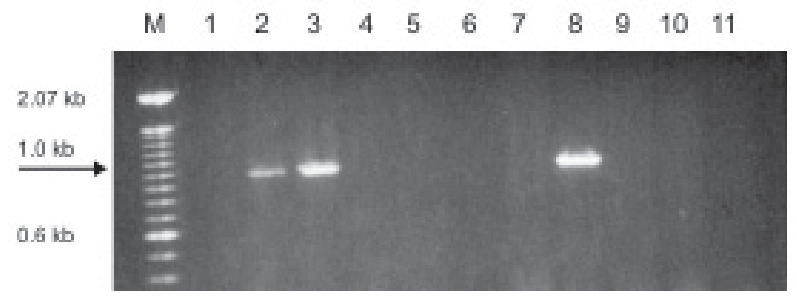

Fig. 1: agarose gel electrophoresis of PCR products generated by amplification of the tet A resistance determinant in tetracycline-resistant Aeromonas strains. Lane - M: 100-bp DNA ladder size marker; 1: negative reaction control (reaction mix without DNA); 2: Acinetobacter strain RUH $2158 \mathrm{H} 5$, used as a positive reaction control. A: Lane - 3: Ac 5.2 (pSS2); 4: Ah 6.4; 5: Ah 149; 6: Ac 26; 7: Ac 6.2; 8: Ac C50; 9: Ac C8; 10: Ah 8; 11: Ah 7.2. B: Lane - 3: Ac 95; 4: Ac 36; 5: Ac 37; 6: Ac 38; 7: Ah 16; 8: Ac 43; 9: Ac 314; 10: Ac $21\left(\mathrm{Tc}^{\mathrm{s}}\right)$; 11: Ah $32\left(\mathrm{Tc}^{\mathrm{s}}\right)$. The arrows indicate the expected size of the amplification product of the tet A gene $(1 \mathrm{~kb})$. Ac: $A$. caviae; Ah: A. hydrophila.
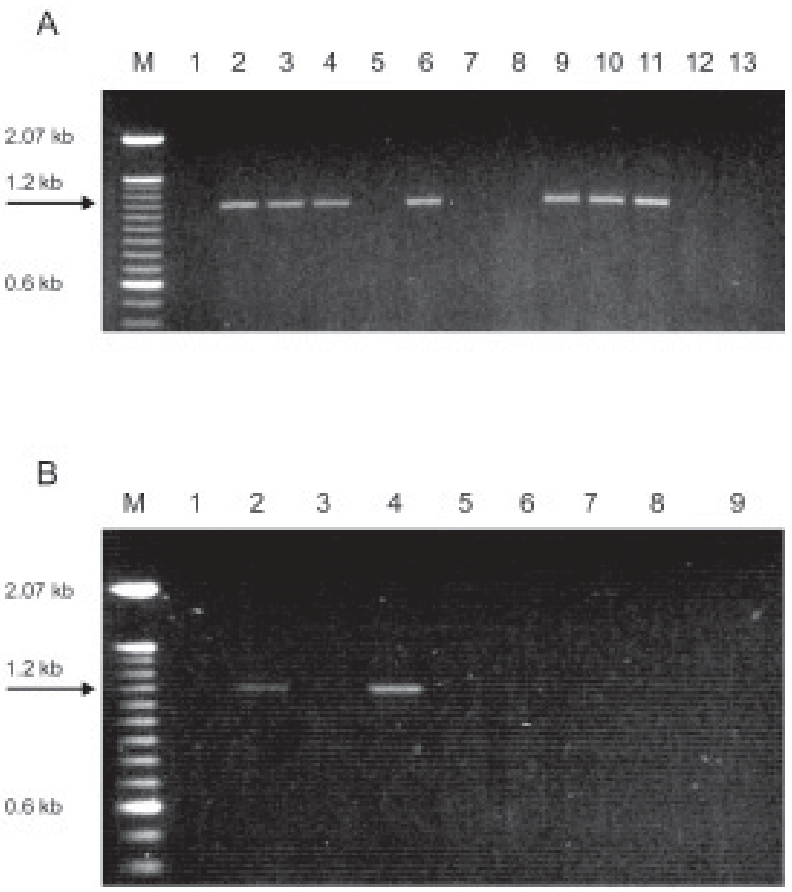

Fig. 2: agarose gel electrophoresis of PCR products generated by amplification of the tetE resistance determinant in tetracycline-resistant Aeromonas strains. Lane - M: 100-bp DNA ladder size marker; 1: negative reaction control (reaction mix without DNA); 2: E. coli strain D22-14, used as a positive reaction control. A: Lane - 3: Ac C50; 4: Ah 6.4; 5: Ac 314; 6: Ah 7.2; 7: Ah 16; 8: Ah 8; 9: Ac 36; 10: Ac 37; 11: Ac38; 12: Ac 21 $\left(\mathrm{Tc}^{\mathrm{s}}\right)$; 13: Ah $32\left(\mathrm{Tc}^{\mathrm{s}}\right)$. B: Lane - 3: Ac 5.2 (pSS2); 4: Ah 149; 5: Ac 26; 6: Ac 6.2; 7: Ac C8; 8: Ac 95; 9: Ac 43. The arrows indicate the expected size of the amplification product of the tetE gene $(1.2 \mathrm{~kb})$. Ac: A. caviae; Ah: A. hydrophila.

Plasmidial involvement in tetracycline resistance - The analysis of the plasmid content demonstrated that only the strain Ac 5.2 out of the 16 tetracycline-resistant Aeromonas spp. strains isolated from lettuce presented a plasmid, whose size was estimated to be $15 \mathrm{~kb}$ (data not shown). This plasmid was named pSS2. Ac 5.2 is one of the strains positive for tetA amplification. This amplification also occurred when the purified pSS2 was used as template.

Plasmid pSS2 was transferred to A. hydrophila ATCC 5677 strain. This strain was tetracycicline-sensitive and, after transformation, it started to exhibit the resistance phenotype. When the selected transformant colonies were submitted to plasmid analysis, it was observed that all contained a plasmid whose size was identical to that of pSS2 (data not shown). The transferred plasmid appeared to be stable in the host strain after growth for some generations in non selective media.

Molecular characterization of pSS2 - According to the lengths of the fragments generated upon the digestion of pSS2 using different restriction enzymes, the size of the plasmid pSS2 was estimated to be $15.4 \mathrm{~kb}$ and its restriction map was created (Fig. 3). 


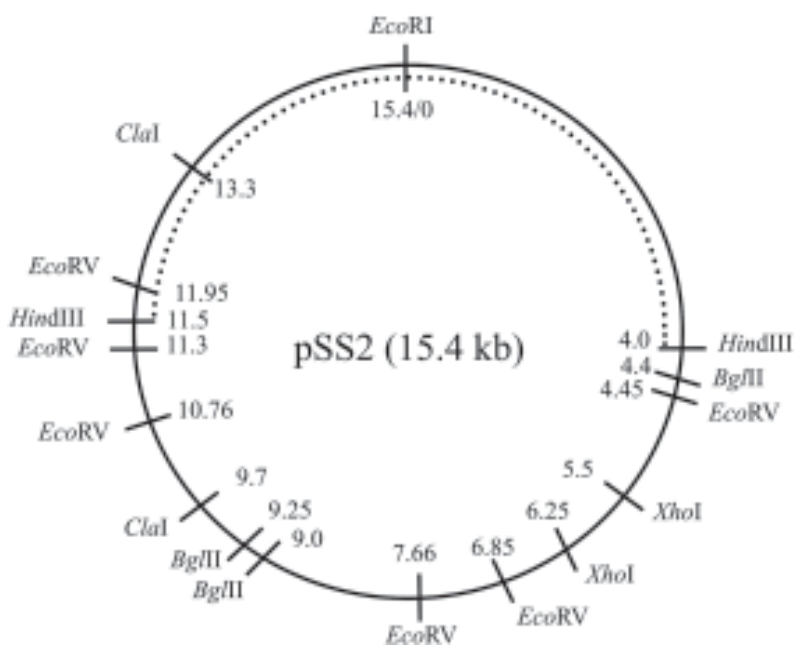

Fig. 3: restriction map of the tetracycline-resistance plasmid pSS2, isolated from the food sample Aeromonas caviae 5.2. According to the lengths of the fragments generated upon digestion of pSS2 using different restriction enzymes, the size of the plasmid pSS2 was estimated to be $15.4 \mathrm{~kb}$. The dashed line indicates the HindIII fragment in which the tetA gene is located.

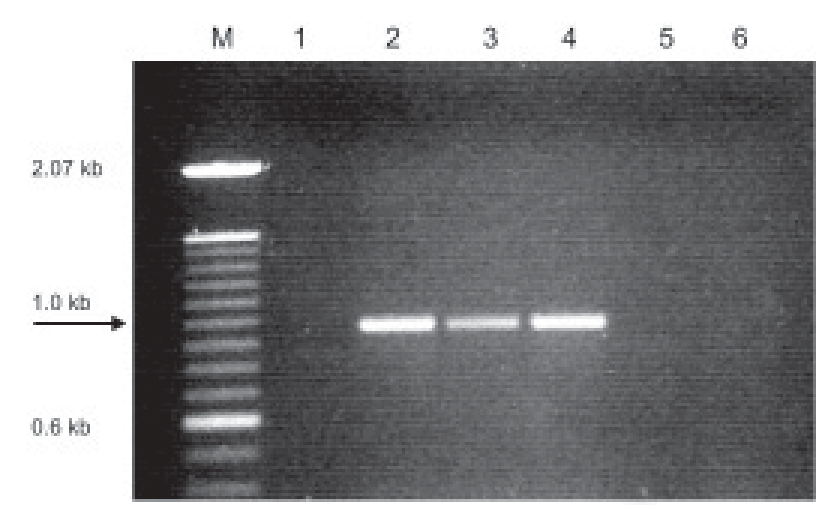

Fig. 4: agarose gel electrophoresis of PCR products generated by amplification of the tet A resistance determinant. Lane - M: 100-bp DNA ladder size marker; 1: negative reaction control (reaction mix without DNA); 2: Acinetobacter strain RUH 2158 H5, used as a positive reaction control; 3: pSS2; 4: recombinant plasmid containing the HindIII-A fragment of pSS2 (7.9 kb); 5: recombinant plasmid containing the HindIII-B fragment of pSS2 $(7.5 \mathrm{~kb}) ; 6$ : pUC18. The arrow indicates the expected size of the amplification product of the tet $\mathrm{A}$ gene $(1 \mathrm{~kb})$.

The digestion of pSS2 with HindIII generated two DNA fragments of different sizes (A and B), which were individually cloned in the multiple cloning site of pUC18. The cloning of the expected fragments was confirmed by digesting the recombinant plasmids with HindIII. To locate the tet $\mathrm{A}$ gene in $\mathrm{pSS} 2$, recombinant plasmids carrying either the HindIII-A or B fragments were used as templates in PCR reactions for tetA. Only the recombi- nant plasmid containing the HindIII-A fragment of pSS2 $(7.9 \mathrm{~kb})$ showed a positive result for the amplification of tetA gene (Fig. 4). Amplification was also obtained when intact pSS2 was used as DNA template. Both pUC18 and the recombinant plasmid carrying the HindIIIB fragment of pSS2 did not exhibit amplification of the tetracycline-resistance determinant.

\section{DISCUSSION}

In the last few decades, an amazing scientific interest in the genus Aeromonas has been observed, since this bacterial group became an emergent human pathogen (Edberg et al. 2007). One of the reasons that might have contributed to that emergence was the high levels of antimicrobial resistance that this pathogen presents. Among all antimicrobial drugs used in the treatment of the Aeromonas-related diseases, tetracycline is one of the most important, since it has been widely used in medicine, agriculture and veterinary (Chopra \& Roberts 2001, Gilchrist et al. 2007). Consequently, even at a subtherapeutical level, tetracycline exerts a selective pressure for resistant bacteria.

There are some reports showing that the tetracyclineresistance determinants most predominant in Aeromonas species are tet $\mathrm{A}$ and tet $\mathrm{E}$ (Schmidt et al. 2001b, Nawaz et al. 2006). Our work is in agreement with the literature. It has also been shown that tet $\mathrm{A}$ and tet $\mathrm{E}$ genes code for an efflux pump that pumps the drug out of the cell (Chopra \& Roberts 2001).

The tetE gene is often associated to large plasmids that are neither mobile nor conjugative (DePaola \& Roberts 1995). The association of this gene with the chromosome was also observed (DePaola \& Roberts 1995, Roberts 1996), which might explain its limited distribution among environmental samples, being more prevalent in polluted marine sediments (Andersen \& Sandaa 1994, Chopra \& Roberts 2001). Nawaz et al. (2006), while describing the tet $\mathrm{E}$ gene, observed the high frequency of this determinant in Aeromonas spp. isolates.

It was observed that $37.5 \%(6 / 16)$ of the tetracyclineresistant Aeromonas spp. strains analyzed were positive only for the amplification of tet $\mathrm{E}$ gene. Five of those samples were isolated from food and only one from a clinical source. None of the tetE positive strains showed the presence of plasmids, suggesting the association of this resistance determinant to the chromosome. Three strains $(18.8 \%)$ were negative for the amplification of both tet $\mathrm{A}$ and tetE genes. Andersen and Sandaa (1994) reported similar results, where no tet determinant was detected in $17 \%$ of their isolates.

The strain Ah 149, isolated from a child with diarrheic faeces in a Brazilian hospital, showed positive amplification for both tet $\mathrm{A}$ and tet $\mathrm{E}$ genes. Despite the fact that most of the Gram-negative isolates carry only one kind of tet gene (Chopra \& Roberts 2001), some authors have also observed the presence of both tet $\mathrm{A}$ and tet $\mathrm{E}$ determinants in some strains, but always in a very low frequency (DePaola et al. 1988, Andersen \& Sandaa 1994, Schmidt et al. 2001a). Although no significant difference in the MIC of strains having one and both tet genes has been observed (Palú et al. 2006), it remains 
unknown whether the presence of two tet determinants in the same cell increases the resistance, since both genes code for efflux pumps.

Our results also showed that $37.5 \%(6 / 16)$ of the tested strains exhibited a positive amplification for only tet A gene. It was not possible to establish a correlation between the sources of these strains and the presence of this gene, as three of these strains were isolated from food (cheese and lettuce), and three of them were isolated from clinical sources.

Among the strains that were positive for the tetA amplification, Ac 5.2 (isolated from lettuce) was the only that harbored a plasmid, which was previously associated to the tetracycline resistance phenotype by curing and transformation experiments (Palú et al 2006). This plasmid was named pSS2. The preliminary molecular characterization of pSS2 was performed by constructing its restriction map. Based on this map, it was possible to estimate its size in $15.4 \mathrm{~kb}$.

The amplification of tetA gene was also observed when the purified plasmid was used as DNA template in $\mathrm{PCR}$, which strongly indicates the correlation between the presence of pSS2 and the tetracycline-resistance of the strain A. caviae 5.2.

The presence of tet A resistance determinant in plasmids isolated from Aeromonas spp. strains has already been reported (Rhodes et al. 2000, Schmidt et al. 2001a, b). It was observed that tetA is generally associated with conjugative plasmids (Chopra \& Roberts 2001). Schmidt et al. (2001a) observed a positive correlation between tetracycline-resistant Aeromonas spp. harboring large conjugative plasmids and the presence of tetA. Our study also observed a positive correlation between $\mathrm{pSS} 2$ and tetA. However, contrary to Schmidt's findings, pSS2 is probably non-conjugative due to its size $(15.4 \mathrm{~kb})$, which is too small to encode for a conjugative apparatus. However, we cannot discard the possibility that pSS2 might be a mobilizable plasmid.

The relationship between the tetracycline resistance of Ac 5.2 strain and the presence of pSS2 was reinforced by the transformation of the plasmid into the tetracycline-sensitive strain A. hydrophila ATCC 5677, which started to exhibit a stable resistance phenotype after the transformation experiment. This result has been previously obtained (Palú et al. 2006), when the tetracycline sensitive strain A. hydrophila ATCC 7966 has been transformed with pSS2. Based on restriction map of pSS2, it was observed that this plasmid has two HindIII-restriction sites. Both HindIII-fragments were then cloned into the pUC18 vector. Recombinant plasmids were used as templates for the amplification reactions for tetA gene. It was possible to confirm that tet $\mathrm{A}$ gene is present on the pSS2 plasmid of the Ac 5.2 strain.

Few works have reported the molecular characterization of drug resistance plasmids in Aeromonas species. This study presents preliminary molecular data about the pSS2 tetracycline-resistance plasmid, allowing it to be compared with new plasmids described, and helping to understand its evolution and spread among the bacterial species, specially species of Aeromonas spp.
The present work shows the presence of tetracycline resistance determinants tet $\mathrm{A}$ and tet $\mathrm{E}$ in Aeromonas spp. strains from Brazil and describes a resistance plasmid that probably contributes to the dissemination of the resistance.

\section{ACKNOWLEDGEMENTS}

To Dr. Lucca Guardabassi and to Dr. Bonnie Marshall, for providing the Acinetobacter strain RUH $2158 \mathrm{H} 5$ and the E. coli strain D22-14, respectively. To thank Eliane de Oliveira Ferreira and Andrew Macrae for the critical reviewing of this manuscript.

\section{REFERENCES}

Alavandi SV, Ananthan S 2003. Biochemical characteristics, serlogroups and virulence factors of Aeromonas species isolated from cases of diarrhoea and domestic water samples in Chennai. Indian J Med Microbiol 21: 233-238.

Andersen SR, Sandaa RA 1994. Distribution of tetracycline resistance determinants among Gram-negative bacteria isolated from polluted and unpolluted marine sediments. Appl Environ Microbiol 60: 908-912.

Araujo RM, Arribas RM, Pares R 1991. Distribution of Aeromonas species in waters with different levels of pollution. J Appl Bacteriol 71: 182-186.

Araújo VS, Pagliares VA, Queiroz MLP, Freitas-Almeida AC 2002. Occurrence of Staphylococcus and enteropathogens in soft cheese commercialized in the city of Rio de Janeiro, Brazil. J Appl Microbiol 92: 1172-1177.

Birnboim HC, Doly J 1979. A rapid alkaline extraction procedure for screening recombinant plasmid DNA. Nucleic Acids Res 7: $1513-1523$

Chopra AK, Houston CW 1999. Enterotoxins in Aeromonasassociated gastroenteritis. Microbes Infect 1: 1129-1137.

Chopra I, Roberts M 2001. Tetracycline antibiotics: mode of action, applications, molecular biology, and epidemiology of bacterial resistance. Microbiol Mol Biol Rev 65: 232-260.

DePaola A, Flynn PA, Mcphearson RM, Levy SB 1988. Phenotypic and genotypic characterization of tetracycline- and oxytetracycline-resistant Aeromonas hydrophila from cultured channel catfish (Ictalurus punctatus) and their environments. Appl Environ Microbiol 54: 1861-1863.

DePaola A, Roberts MC 1995. Class D and E tetracycline resistance determinants in gram-negative catfish pond bacteria. Mol Cell Probes 9: 311-313.

Edberg SC, Browne FA, Allen MJ 2007. Issues for microbial regulation: Aeromonas as a model. Crit Rev Microbiol 33: 89-100.

Evangelista-Barreto NS, Vieira RHSF, Carvalho FCT, Torres RCO, Sant'anna ES, Rodrigues DP, Cristhiane MF, Reis CMF 2006. Aeromonas spp. isolated from oysters (Crassostrea Rhizophorea) from a natural oyster bed, Ceará, Brazil. Rev Inst Med Trop São Paulo 48: 129-133.

Garibay RIA, Aguilera-Arreola G, Ocaña AN, Cerezo SG, Mendoza MS, López JM, Campos CE, Cravioto A, CastroEscarpulli G 2006. Serogroups, K1 antigen, and antimicrobial resistance patterns of Aeromonas spp. strains isolated from different sources in Mexico. Mem Inst Oswaldo Cruz 101: 157-161.

Gilchrist MJ, Greko C, Wallinga DB, Beran GW, Riley DG, Thorne PS 2007. The potential role of concentrated animal feeding operations in infectious disease epidemics and antibiotic resistance. Environ Health Perspect 115: 313-316. 
Goñi-Urriza M, Capdepuy M, Arpin C, Raymond N, Caumett P, Quemtin C 2000. Impact of an urban effluent on antibiotic resistance of riverine Enterobacteriaceae and Aeromonas spp. Appl Environ Microbiol 66: 125-132.

Guardabassi L, Dijkson L, Collard JM, Olsen JE, Dalsgaard A 2000. Distribution and in vitro transfer of tetracycline resistance determinants in clinical and aquatic Acinetobacter strains. J Med Microbiol 49: 929-936.

Joseph SW, Carnaham AM 2000. Update on the genus Aeromonas. ASM News 66: 218- 223.

L'Abée-Lund TM, Sorum H 2002. A global non-conjugative Tet C plasmid, pRAS3, from Aeromonas salmonicida. Plasmid 47: 172-181.

Marshal B, Morrisey S, Flynn P, Levy SB 1986. A new tetracycline-resistance determinant, class E, isolated from Enterobacteriaceae. Gene 50: 111-117.

Martins LM, Marquez RM, Yano T 2002. Incidence of toxic Aeromonas isolated from food and human infection. FEMS Immunol Med Microbiol 32: 237-242.

Nawaz M, Sung K, Khan SA, Khan AA, Steele R 2006. Biochemical and molecular characterization of tetracycline-resistant Aeromonas veronii isolates from catfish. Appl Environ Microbiol 72: 6461-6466.

Palú AP, Gomes LM, Miguel MAL, Balassiano IT, Queiroz ML, Freitas-Almeida AC, Oliveira SS 2006. Antimicrobial resistance in food and clinical Aeromonas isolates. Food Microbiol 23: 504-509.

Rhodes G, Huys G, Swings J, Mcgann P, Hiney M, Smith P, Pickup RW 2000. Distribution of oxytetracicline resistance plasmids between Aeromonads in hospital and aquaculture environments: implication of $\mathrm{Tn} 1721$ in dissemination of the tetracycline resistance determinant tetA. Appl Environ Microbiol 66: 3883-3890.
Roberts MC 1996. Tetracycline resistance determinants: mechanisms of action, regulation of expression, genetic mobility, and distribution. FEMS Microbiol Rev 19: 1-24.

Sambrook J, Fritsch EF, Maniatis T 1989. Molecular cloning: a laboratory manual. Cold Spring Harbor Laboratory Press, Cold Spring Harbor, New York, 2344 pp.

Schleif RF, Wensink PC 1981. Pratical Methods in Molecular Biology. Spring-Verlag, New York, 220 pp.

Schmidt AS, Bruun MS, Dalsgaard I, Larsen JL 2001a. Incidence, distribution, and spread of tetracycline resistance determinants and integron-associated antibiotic resistance genes among motile Aeromonas from a fish farming environment. Appl Environ Microbiol 67: 5675-5682.

Schmidt AS, Bruun MS, Larsen JL, Dalsgaard I 2001b. Characterization of class 1 integrons associated with R-plasmids in clinical Aeromonas salmonicida isolates from various geographical areas. J Antimicrob Chemother 47: 735-743.

Son R, Rusul G, Sahilah AM, Zainuri A, Raha AR, Salmah I 1997. Antibiotic resistance and plasmid profile of Aeromonas hydrophila isolates from cultured fish, Telapia (Telapia mossambica). Lett Appl Microbiol 24: 479-482.

Szabo EA, Schurrah KJ, Burrows JM 2000. Survey for psychrotrophic bacterial pathogens in minimally processed lettuce. Lett Appl Microbiol 30: 456-460.

Tovar K, Ernst A, Hillen W 1988. Identification and nucleotide sequence of the class $\mathrm{E}$ tet regulatory elements and operator and inducer binding of the encoded purified Tet repressor. Mol Gen Genet 215: 76-80.

Yanisch-Perron C, Vieira J, Messing J 1985. Improved M13 phage cloning vectors and host strains: nucleotide sequences of the M13mp18 and pUC19 vectors. Gene 33: 103-119. 